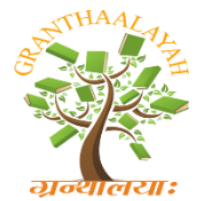

INTERNATIONAL JOURNAL OF RESEARCH GRANTHAALAYAH A knowledge Repository

Science

\title{
EFFECT OF SEQUENTIAL CONCENTRATIONS OF ZINC AND ITS COMBINATION WITH CALCIUM OR GLUTATHIONE ON THE GROWTH, WATER RELATIONS AND ANATOMY OF ROOTS, STEMS AND LEAVES OF PHASEOLUS VULGARIS CV. CONTENDER
}

\author{
Wafaa M. Shukry ${ }^{1}$, A.A. Al-Osaimi ${ }^{2}$ \\ ${ }^{1}$ Botany Department, Faculty of Science, Mansoura University, Mansoura, Egypt \\ ${ }^{1}$ Faculty of Science for Girls, Dammam University, Saudi Arabia \\ ${ }^{2}$ Biology Department, College of science, Imam Abdulrahman Bin Faisal University Saudi \\ Arabia
}

\begin{abstract}
Zinc $(\mathrm{Zn})$ is one of the eight essential micronutrients. It is needed by plants in small amounts, but yet crucial to plant development. A solution culture experiment was conducted to study the variation in growth, water relations and anatomy of roots, stems and leaves of Phaseolus vulgaris cv. contender treated with 1, 200, 400, 600, 800, 1000and $1200 \mathrm{mMZnSO}_{4}$. Maximum significant deplete in parameters of growth (Length of root and shoot; fresh and dry weights, relative growth rate; $\mathrm{N}^{\circ}$ of leaves and leaf area), stomatal index and rate of transpiration was observed with, 200, $400,600,800,1000$ and $1200 \mathrm{mM} \mathrm{ZnSO}_{4}$. These effects were improved by the addition of $\mathrm{Ca}^{2+}$ than the addition of glutathione at $10 \mathrm{mM}$. Moreover, there were a significant increase at low concentration $(1 \mathrm{mM})$ treatment. Width of root, width of cortex and width of vascular bundles were increase with increasing $\mathrm{Zn}$ concentrations either alone or in combination with glutathione $>\mathrm{Ca}$ $\left(\mathrm{NO}_{3}\right)_{2}$. For stem, the $\mathrm{N}^{\mathrm{o}}$ of vascular bundles were decreased with increase in $\mathrm{Zn}$ concentration alone and with $\mathrm{Ca}\left(\mathrm{NO}_{3}\right)_{2}$, meanwhile increase with glutathione. Width of cortex and $\mathrm{N}^{\mathrm{o}}$ of its rows were decrease with increase Zn concentrations. For leaves, the thickness of leaf blade, mid rib and vascular bundle were increase with increase the $\mathrm{Zn}$ concentrations alone, On other hands, they records a significant decrease in combination of $\mathrm{Zn}$ with $\mathrm{Ca}\left(\mathrm{NO}_{3}\right)_{2}$ or glutathione . In general, an increase in total uptake of zinc with increasing the concentration of $\mathrm{Zn}$ in all treatments. However, $\mathrm{Ca}\left(\mathrm{NO}_{3}\right)_{2}$ decrease these amounts than glutathione.
\end{abstract}

Keywords: Zinc; Calcium Nitrate; Glutathione; Growth; Anatomy; Phaseolus Vulgaris.

Cite This Article: Wafaa M. Shukry, and A.A. Al-Osaimi. (2019). "EFFECT OF SEQUENTIAL CONCENTRATIONS OF ZINC AND ITS COMBINATION WITH CALCIUM OR GLUTATHIONE ON THE GROWTH, WATER RELATIONS AND ANATOMY OF ROOTS, STEMS AND LEAVES OF PHASEOLUS VULGARIS CV. CONTENDER.” International Journal of Research - Granthaalayah, 7(11), 1-18. 10.29121/granthaalayah.v7.i11.2020.329. 


\section{Introduction}

The term "heavy metal" commonly refers to metals with a specific weight in excess of $5 \mathrm{~g} / \mathrm{cm}$ or anatomical number in excess of 20. Such properties are our significance for biological effects, yet the heavy metals contain essential nutrients, beneficial elements and elements that are not known to be active in humans at the present stage of science. At relatively low levels, all of them become harmful. Yet toxicity is not an exclusive aspect of heavy metals listed elements. The heavy metals are therefore a rather heterogeneous group of elements which differ greatly in their chemical properties and biological functions. The word "heavy metal" is therefore debunked (Nieboer and Richardson 1980). But as Tiller (Tiller 1989) pointed out "heavy metal may be a useful umbrella term for metals classed as environmental pollutants". Among the myriad of heavy metals zinc occupies the prominent position, since it plays a vital role in the growth and development of plants. Zinc, one of the essential micronutrients and an important constituent of a number of enzymes and proteins, is required only in small quantities by plants. However, plant development is crucial, as it plays a significant role in a wide range of processes. The normal range for zinc in plant tissue is between 15-60 ppm and between 0.10-2.0 ppm in the growing medium. Zinc deficiency or toxicity is not common; however, both negatively impact crop growth and performance. Any deficiency or toxicity must be addressed prior to irreversible crop damage.

Zinc release to the atmosphere may be correlated with biotic and natural atmospheric processes, with a ratio of $\mathrm{Zn}$ emissions from human activities to those from natural causes exceeding 20 .

(Friedland 1990). Human activities that release $\mathrm{Zn}$ to the atmosphere include fossil fuel combustion and the use of sewage sludge, manure and lime. Many crops may suffer from $\mathrm{Zn}$ toxicity in polluted and acidic soils, and species with high $\mathrm{Zn}$ uptake potential, such as spinach and beet, may be more prone to its abundance. (Chaney 1993; Broadleyet al., 2007). Bioaccumulation of trace metals in plant tissues can pose a risk to the health of wildlife and human beings (Singh and Agrawal 2007).

Calcium is considered to have a positive influence on plant growth and to enhance heavy metal toxicity. (Marschner, 1995; Hagemeyer, 1999). In addition, Ca was found to decrease the content of $\mathrm{Cd}, \mathrm{Cu}, \mathrm{Mn}$ and $\mathrm{Zn}$ in plant roots and/or shoots (Kawasaki and Moritsugu, 1987; Salehet al., 1999). In order to handle different types of metals, plants have protection techniques linked to cellular free metal content (e.g., metal exclusion, cell wall binding, chelation and sequestration) on one side. (Hall, 2002) However, on the other hand, control of cellular responses (e.g. repair of stress-damaged proteins, antioxidant protection). (Hall, 2002). The synthesis of specific chelators and subsequent sequestration of metal complexes is of major importance to limit free metal concentrations. Glutathione (GSH) is a key component of such metal scavenging due to the high metal affinity with its thiol (-SH) group and as a phytochelatin precursor (PC). In addition to metal homeostasis, plants have a well-equipped antioxidant defense system to deal with the metalimposed oxidative challenge (Jozefczaket.al. 2012).

Phaseolus vulgaris, also referred to as the common bean, Gentry, Howard Scott (1969) green bean and French bean, among other names, is a herbaceous annual plant grown worldwide for its edible dry seeds or unripe fruit (both commonly called beans). The main categories of common beans, on the basis of use, are dry beans (seeds harvested at complete maturity), The common bean grows well on large variable soils with $\mathrm{pH}$ ranging from 4 to 9. It grows better on well-drained, 
sandy loam, silt loam or clay loam soils, rich in organic matter content. Dry beans production (theoretically only Phaseolus species) was about 23 million ton in 2012, cultivated on 29 million ha (FAO, 2013)In recent years, consumption of legumes particularly dry beans ( Phaseolus vulgaris L.) has increased in some West European countries and the United States. This is due to an increased realization of consumers about the nutritional characteristics in foods.

The goal of this study was to investigate the effects of high nutrient solution concentrations of $\mathrm{Zn}$ on growth, water relationships, $\mathrm{Zn}$ content and anatomy characteristics composition of different parts of the plant bean model (Phaseolus vulgaris L.). The objective was also to determine the role of calcium and glutathione in improving zinc toxicity in plants of Phaseolus vulgaris.

\section{Materials and Methods}

\section{Time Course Experiment}

A homogenously-sized lot of Phaseolus vulgaris cv. contender) seeds was kindly supplied by the agriculture research center, Ministry of agriculture, Giza, Egypt. The seeds were selected, and surface sterilized by soaking in $0.01 \% \mathrm{HgCl}_{2}$ solution for about $3 \mathrm{~min}$, then washed thoroughly with continuously flowing tap water for about $1 \mathrm{~h}$. After this, 25 seeds were allowed to germinate in plastic dishes (length: $30 \mathrm{~cm}$; width: $20 \mathrm{~cm}$; height: $12 \mathrm{~cm}$ ), covered with Whatman filter paper No. 1 and watered with equal amounts of Hoagland's nutrient solution (Arnon and Hoagland 1940). The nutrient solution used was $1 / 4$ strength of Pfeffer (1900) nutrient mixture of macro elements. Micronutrients were supplied to the nutrient solution at concentrations used by Arnon and Hoagland (1940). All chemicals used were of the purest grade available from Sigma-Aldrich. The $\mathrm{pH}$ value of this nutrient solution was $5.7 \pm 0.3$. The dishes were incubated in the dark at 25 $\pm 1^{\circ} \mathrm{C}$ to allow seeds to germinate. After $48 \mathrm{~h}$ six uniform seedlings (the length of the radical was about $2 \mathrm{~cm}$; leaves had not yet differentiated were placed in black-painted beakers $(600 \mathrm{ml})$ containing $1 / 4$ strength Hoagland's nutrient solution either alone or supplemented with the addition of $\mathrm{Ca}\left(\mathrm{NO}_{3}\right)_{2}$ or glutathione at $10 \mathrm{mM}$. The beakers were placed in a growth chamber adjusted at optimum growth conditions: temperature: $28 \pm 2{ }^{\circ} \mathrm{C}$; light intensity: 3000- 5000 lux; relative humidity: 60-70\%; continuous aeration from an air pump at a rate of $2 \mathrm{~L} / \mathrm{h} /$ beaker according to Steing Rover (1983).

Throughout the experimental period, various growth parameters, stomatal index, stomatal area, rate of transpiration, content of zinc in root and shoot were determined. In addition, the changes in the internal structure of root, shoot and leaves were determined.

Data from the different groups of seedlings were statistically analyzed and comparison among means was carried out using Statgraphic Ver. 4.2, Display (one-tailed ANOVA), as described by Snedecor and Cochran 1980).

\section{Growth Parameters}

The plant heights from the root system intersection to the stem's growing tip were measured and at the end of the experiment (14-day old) root length was determined. The fresh weights and dry weights of the shoots and roots were obtained using an electronic balance. As well as number of leaves and leaf area were determined. 


\section{Relative Growth Rate (RGR)}

Relative growth rate (RGR) was calculated according to (Hofmann and Poorter 2002) formula:

$$
(\mathrm{RGR})=\left(\operatorname{Loge}_{2}-\log _{\mathrm{e}} \mathrm{W}_{1}\right) /\left(\mathrm{T}_{2}-\mathrm{T}_{1}\right)
$$

Where $\mathrm{W}_{1}$ and $\mathrm{W}_{2}$ are the dry masses at 7 and 14 - day harvest $\mathrm{T}_{1}$ and $\mathrm{T}_{2}$ respectively on the basis that growth was exponential during this growth period.

\section{Rate of Transpiration}

The rate of transpiration was estimated gravimetrically from the decrease in the weight of the whole plant and culture solution on the basis of root fresh mass as mg g- ${ }^{1}$ fresh mass $\mathrm{h}^{-1}$. (Youniset al., 1992).

$$
\text { Rate of transpiration }=\quad \mathrm{W}_{1}-\mathrm{W}_{2}
$$

F. wt of root $\mathrm{x}$ time of experiment in hours $(48 \mathrm{hr})$

$$
=\mathrm{mg} / \mathrm{g}^{-1} \mathrm{~F} \text {. Wt root }
$$

$\mathrm{W}_{1}=$ weight of plant at the beginning of experiment

$\mathrm{W}_{2}=$ weight of plant at the end of experiment

\section{Determination of the Stomatal Index}

The stomatal number (stomatal density) is called the total number of stomata per square millimeter of epidermis. According to the stomatal index, the percentage proportional to the ultimate divisions of the epidermis of a leaf that has been converted into stomata (Weyers and Meidner, 1990):

Stomatal Index $=\underline{\text { Stomatal density } \mathrm{x} 100}$

$$
\text { Stomatal density +density of epidermal cells }
$$

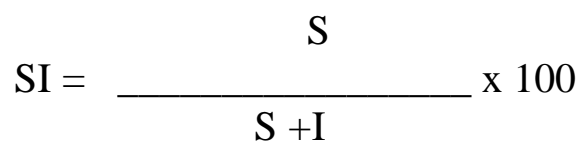

Where SI = Stomatal index, $\mathrm{S}=$ number of stomata per unit area and $\mathrm{E}=$ number of ordinary epidermal cells in the same unit area.

\section{Procedure}

Pieces of the leaf between the margin or midrib were cleaned and mounted, and the lower surface was examined using a $4 \mathrm{~mm}$ objective microscope and an eyepiece with a $5 \mathrm{~mm}$ square micrometer disk. The numbers of the epidermal cells and the stomata within a square grid were counted, a cell being counted if at least half of its area is within the grid. The index of stomas was calculated for both surfaces of the leaf.

\section{Chemical Analysis}

The plants were harvested at the age of 14, shoots and roots, and the roots were washed with deionized water and the samples were dried for chemical analysis at $80 \mathrm{oC}$ in an oven for $48 \mathrm{~h}$. Then dry shoots and roots were weighed and grounded. Plant samples $(0.5 \mathrm{~g})$ were digested with 
concentrated $\mathrm{HNO}_{3}$ and $\mathrm{H}_{2} \mathrm{O}_{2}$ (Jackson, 1958; Han et al., 2004). The digested solution was filtered and then analyzed for $\mathrm{Zn}$ atomic absorption spectrophotometry (ICP-AES-Liberty series II) (Han and Banin 1997). Calculated as mM/100gm Dry weight.

\section{Anatomical Preparation}

For anatomical investigation, samples from plants were taken after ending the experiment (about 14-days-old). Stem sample were taken from the first internode after the $1^{\text {st }}$ foliage leaf. Leaf samples were taken from $1^{\text {st }}$ trifoliate leaf. Root samples were taken $5 \mathrm{~cm}$ away from the point of attachment of root and shoot. Plant material was fixed in FAA ( Formalin, acetic acid and alcohol : 1:1:1 ) dehydrated, paraffin embedded, ultramicrotomed and subjected to safranin $(0.1 \%)$ - fast green $(0.2 \%)$ staining for further observation (Sass 1958).In these sections, thickness of section , number of cortical cells (raws), width of cortical cells, number of vascular bundels in root and stem were determined. In leaf sections, the blade thickness, Midrib thickness and Width of vascular bundle were determined using linear micrometr. (Shukry 1986).

\section{Results and Dissection}

Zinc $(\mathrm{Zn})$ is an essential component of thousands of proteins in plants, although it is toxic in excess. Zinc toxicity in crops is far less widespread than $\mathrm{Zn}$ deficiency. However, $\mathrm{Zn}$ toxicity occurs in soils contaminated by mining and smelting activities, in agricultural soils treated with sewage sludge, and in urban and peri-urban soils enriched by anthropogenic inputs of Zn, especially in low-pH soils (Chaney 1993). Toxicity symptoms usually become visible at $[\mathrm{Zn}]_{\text {leaf }}>$ $300 \mathrm{mg} \mathrm{Zn} \mathrm{kg}^{-1}$ leaf DW, although some crops show toxicity symptoms at $[\mathrm{Zn}]_{\text {leaf }}<$ $100 \mathrm{mg} \mathrm{Zn} \mathrm{kg}{ }^{-1}$ DW (Chaney, 1993; Marschner, 1995).

\section{Effect of Zn Treatments on Plant Growth and Water Relations of Phaseolus Vulgaris}

Different growth parameters of intact Phaseolus plants ( shoot and root length ; fresh and dry weights; ) as shown in figure 1 and ( number of leaves, leaf area ); number of stomata, stomatal area, relative water contents and rate of transpiration as shown in table 1 showed a significant increase in growth at low concentration ( $1 \mathrm{mM})$. This result may explained that $\mathrm{Zn}$ serves as a promoter of development micronutrients at low concentrations Sridhar et al. (2007). Since Zn is required for the synthesis of tryptophan (Brown et al., 1993; Alloway, 2004), which is a precursor of IAA, this metal also has an active role in the production of auxin, an essential growth hormone (Brennan, 2005; Tsonev and Lidon 2012).

However, at the high concentrations (200, 400, $600,800,1000 \& 1200 \mathrm{mM} \mathrm{ZnSO} 4)$, showed a general decrease in all growth parameters with increasing $\mathrm{Zn}$ concentration. These results are in accordance with those obtained by Bonnet et al (2000) in ryegrass plants and Shute and Macfie (2006) in soybean. The same trend was observed in RGR. Meanwhile, S/R ratio was increased with increasing $\mathrm{Zn}$ concentration, this indicate that, the root is more sensitive than the shoot. The reason for the different responses of root and shoot growth to heavy metals is not clear, but may be partly due to faster accumulation of heavy metals in the root than in shoots or a faster detoxification rate in the shoot than the root (Al-Yemeni andAl-Helal.2002Who reported that $\mathrm{ZnCl} 2$ significantly inhibited the root and shoot elongation of rice seedlings and increased the degree of inhibition as the concentration increased. Radical elongation has been more detrimental than shooting elongation. Zengin (2006) It stated that, Phaseolus vulgaris cv treatments. For $\mathrm{Zn}^{2+}$, 
the abscisic acid content in the root and in the leaves increased significantly. The rise in leaf abscisic acid was correlated with the root material.

Shaukat, et.al (1999) suggested that shooting heavy metal concentrations lead to high phenolic compounds that could be responsible for germination and growth inhibition. Phenolic acids have been shown to exert dramatic effect on membrane permeability and membrane electrical potentials. Zn concentrations of 100-400 $\mu \mathrm{g}$ g-1(soil d.m.) cause significant decrease in root and shoot growth parameters at different developmental stages of Artemisia annua plants and the biomass decline and inhibition of cell elongation and division (Khudsar et al., 2004)

Zinc In Zn- (Table 2), accumulation in plant shoots and roots increased significantly $(\mathrm{P}<0.05)$ either alone or in incompatibility with $\mathrm{Ca}^{+2}$ or glutathione treated groups with increased concentration of applied metal solution. There were a negative correlations between $\mathrm{Zn}$ accumulation in shoots and roots to RWC, plant fresh and dry weight and plant height (Fig. 1). Meanwhile, there were a positive correlations with S/R ratio, this may indicate that, the root is more sensitive to Zn than shoot. Sresty and MadhavaRao (1999) based on transmission electron microscopy concluded that radicle elongation was more adversely affected than the plumule extension. The major change was seen in the nucleus of the root tip cells due to zinc toxicity. The chromatin material was highly condensed and some of the cortical cells showed disruption and dilation of nuclear membrane in presence of $7.5 \mathrm{mM}$ zinc. The cytoplasm became structureless, disintegration of cell organelles and the development of vacuoles were also observed. Rout and Das (2003). Also, it was found that, Phenolic contents were substantially elevated in both shoots and roots following treatment with heavy metals particularly at high concentrations (200 and 400 ppm). Shaukat et.al.(1999).

A significant decrease in dry weight may be due to decrease in protein content, this in accordance with those obtained by Zengin,. (2006). The contents of total protein decreased with the concentration of zinc. Number of leaves and leaf area was significantly decrease with increase $\mathrm{Zn}$ concentration, this is in agreement with those obtained by(Khudsar et al (2004)), where they found that, the Responses of Artemisia annua to different concentrations of zinc [50, 100, 200, 300 and $400 \mu \mathrm{g} \mathrm{g}^{-1}$ (soil dry mass)]. Total leaf area, dry mass of leaves, length and dry mass of shoots and roots declined significantly under the influence of $\mathrm{Zn}$ treatment .Similar results were also reported by Chamon et al., (2008) who , showed that the application of $\mathrm{Zn}$ to soils had a slight negative influence on nitrogen content in stems of spinach, may be the reason for negative influence in case of red amaranth (Malik et al. 2011). Sedberry et al., (1988) found that $\mathrm{Zn}$ application resulted in a reduction in $\mathrm{P}$ concentration in rice plant tissue at first joint, may also be another reason for yield reduction. As clear from table 1, the rate of transpiration increased significantly with increasing $\mathrm{Zn}$ concentration, this also correlated with increasing the stomatal area although the no of stomata decreased with decrease the leaf area. In this respect, Hoe et.al. (2012) stated that, Transpiration of plants has an important role in heavy metal absorption. When the transpiration is flourishing, plants accumulate more heavy metals, and its enrichment capability is also stronger.

Meanwhile the stomatal index was decreased with increasing $\mathrm{Zn}$ concentrations at all treatments, this results was confirmed with Kasim (2007), who found that, The Zn-induced 6-fold increase in 
stomatal deformation, reduction in frequency of normal stomata in of Phaseolus vulgaris L. cv. Limburgsvroege were sown in peat moss supplemented with $\mathrm{ZnSO}_{4}(600 \mathrm{mg} \mathrm{kg})$.

Glutathione combination can mitigate the plant's toxic effect of $\mathrm{Zn}$. In particular, when taken in excessive amounts, all metals can contribute to toxicity and oxidative stress, which poses a serious threat to the environment. Plants have defensive strategies in which glutathione (GSH; $\pi$-glu-cysgly) plays a central role as a chelating agent, antioxidant and signaling element in order to cope with different types of metals. This analysis therefore emphasizes GSH's role in: (1) metal homeostasis; (2) antioxidant defense; and (3) metal stress signal transduction. GSH's various functions come from the cysteine sulfhydryl group, allowing GSH to chelate metals .and participates in redox cycling. Jozefczak et.al. (2012).

The combination of $\mathrm{Ca}+2$ can alleviate the toxic effect of $\mathrm{Zn}$ on plants more than glutathione. For $\mathrm{Ca}^{2+,}$ three mechanism of alleviation have been identified (Kinraide, 1998).

Mechanism $I$ is the electrostatic displacement of cationic toxicants from the plasma membrane (PM)surface. Addition of $\mathrm{Ca} 2+$ salts to the rooting medium causes a reduction in the negative potential at the outer surface of the PM because of ionic screening and binding, thereby reducing the electrostatic attraction of cationic toxicants. Because of their equal charge and strength of binding to the PM, Ca2+ and $\mathrm{Mg}^{2+}$ haveequal effectiveness as Mechanism I ameliorants. Al3+and $\mathrm{H}+$ have even higher Mechanism I effectiveness (Grauer and Horst, 1990; Kinraide, 2003) even though both ions are also intoxicating. $\mathrm{Na}+$ and $\mathrm{K}+$ also alleviate toxicity by Mechanism I, but much more weakly than $\mathrm{Ca} 2+$ and $\mathrm{Mg} 2+$ Mechanism II is the restoration of $\mathrm{Ca} 2+$ at the $\mathrm{PM}$ surface. Extracellular $\mathrm{Ca}^{2+}$ is essential for root elongation even in the absence of toxicants. If a toxic anthas sufficiently displaced $\mathrm{Ca} 2+$ from the PM surface (by toxicant-induced reduction of surface negativity, or by other means), then the addition of $\mathrm{Ca}^{2+}$ willengage Mechanism II. $\mathrm{Mg} 2+$, of course, has no Mechanism II effectiveness; in fact, it may induce $\mathrm{Ca}^{2+}$ insufficiency. Induced $\mathrm{Ca}^{2+}$ insufficiency is a component, though not usually the major component, of toxicity induced by low $\mathrm{pH}$ or high salinity (Kinraide,1998, 1999). Mechanism III is the residual alleviation beyond Mechanisms I and II. It is a heterogeneous suite of mechanisms that may entail interactions between $\mathrm{Ca}^{2+}$ and the toxicant at the PM surface

\section{Effect of Zinc Treatment on Zn Concentration in P. Vulgaris}

The effect of zinc treatment on its come into roots and shoots of $P$. vulgaris are presented in table 2. The results were highly significant at all levels of Zinc in the solution culture influenced it's concentration in $P$. vulgaris. It was observed that when the zinc levels in solution increased its concentrations in roots were also increased. Zinc was accumulated in roots and shoots. The average $\mathrm{Zn}$ concentration ranged from 0.416 to $35.91 \mathrm{mM}$ in roots in treatment with $\mathrm{Zn}$ alone, and from 0.60 to $33.00 \mathrm{mM}$ in combination of $\mathrm{Zn}$ with $\mathrm{Ca}\left(\mathrm{NO}_{3}\right)_{2}$ and from 0.69 to 61.63 in combination with glutathione. A gradual increase of zinc concentration was observed with the increasing $\mathrm{Zn}$ levels. In shoots $\mathrm{Zn}$ concentration was also found to increase with increasing $\mathrm{Zn}$ levels. The $\mathrm{Zn}$ concentration in P.vulgaris shoots was found lowest than in the roots. Roots accumulate more $\mathrm{Zn}$ than shoots. In general, total uptake of $\mathrm{Zn}$ decreased in supplementation of $\mathrm{ZnSO} 4$ with $\mathrm{Ca}\left(\mathrm{NO}_{3}\right)_{2}$ than with glutathione . 


\section{Effect of Zn Accumulation on Plant Internal Structure}

Following the results in Table (3) and images (2), there was an increase in the root thickness. This coincided with an increase in the density of the vascular area and vascular bundles in the case of zinc alone or glutathione. This may be due to the increased surface exposure of the elements. Gadallah and Ramadan (1997) show that high concentrations of zinc enhanced xylem formation in the roots of CarthamustinctoriusL. While Rosolem et al. (2005) stated that Plants grown without $\mathrm{Zn}$ showed an increase in root and in root stele diameter.

For the stem, as shown in table (4) and plate (3) It was found that there was a decrease in width of the cortex and concurrent with the decrease in number of rows of cortical cells and the number of vascular bundles with increased concentration of zinc alone or in combination with calcium nitrate or glutathione, noting that there is an improvement in the case of the addition of glutathione.This may be due to the fact that high concentrations of zinc may affect the rate of formation of auxins, which affects the rate of growth. On the other hand, Alpaslan et al. (1999) added that the addition of zinc to tomato plant with sodium chloride lead to increase the number of vascular bundles in the stem.

In leaf anatomy as shown in table (5) and plate (4), it was shown that, the thickness of the leaf in the zinc-treated plants alone was increased with increasing zinc concentration. This was coinciding with the increase in thickness of the midrib area and the expansion of the vascular bundle area. With the addition of calcium nitrate, there was a decrease in these measurements with increasing zinc concentration. However, with the addition of glutathione, the thickness of leaf and a decrease in the mid rib area, while the thickness of the vascular bundle area did not show a change. Sidhar et al. (2007) suggests that, the, microscopic structural changes, such as a decrease in intercellular spaces, breakdown of vascular bundles, and shrinkage of palisade and epidermal cells, occurred in leaves, stems and roots of plants treated with high concentrations of $\mathrm{Zn}$.

Shoots and roots of $P$. vulgaris seedlings seemed to show differential sensitivity to $\mathrm{Zn}$ stress. Reduction in shoot growth criteria seemed to result from a decrease in parenchyma cell size and diameters of metaxylem vessels in the leaf midrib. Scanning Electron Microscope (SEM) revealed the presence of compacted grana with reduced thylakoids in chloroplasts, which might have contributed to the recorded loss of chl-a, chl-b and carotenoids Kasim (2007)

\section{Conclusion}

Zinc added at the rates of, 200, 400, 600, 800, 1000 and $1200 \mathrm{mM}$ ZnSO4. Maximum significant decrease in the growth affected the height of Phaseolus vulgaris plants significantly. At $1 \mathrm{mM} \mathrm{Zn,}$ plant height was found to be highest $(29.21 \mathrm{~cm} /$ plant $)$ and then decreased with increasing $\mathrm{Zn}$ treatments. Fresh and dry matter production of Phaseolus vulgaris decreased with increasing $\mathrm{Zn}$ levels and found highest at $1 \mathrm{mM}$. Zn concentration in plants increased with increasing $\mathrm{Zn}$ treatment and was highest at $1200 \mathrm{mM}$ in all treatments either in application of $\mathrm{Zn}$ alone or in combination with $\mathrm{Ca}^{+2}$ or with glutathione in both for root and shoot. There was a differential variation in anatomical structure of roots, stems and leaves owing to all treatments with zinc. 
Table 1: Effect of different $\mathrm{ZnSO} 4$ concentrations in the culture medium either alone or in combination with $10 \mathrm{mM} \mathrm{Ca}(\mathrm{NO} 3) 2$ on shoot/root ratio, relative growth rate (RGR);number leaves; leaf area; stomatal Index; stomatal area and rate of transpiration

\begin{tabular}{|c|c|c|c|c|c|c|c|c|}
\hline Treatment & Concentrations & $\mathbf{S} / \mathbf{R}$ & RGR & $\begin{array}{l}N^{0} \text { of } \\
\text { leaves }\end{array}$ & $\begin{array}{c}\text { leaf area } \\
\left(\mathrm{cm}^{2}\right)\end{array}$ & $\begin{array}{l}\text { Stomatal } \\
\text { Index }\end{array}$ & $\begin{array}{l}\text { Stomatal } \\
\text { area } \mu 2\end{array}$ & 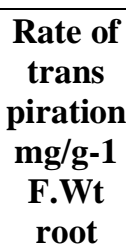 \\
\hline \multirow[t]{9}{*}{ ZnSO4 } & Control & $\begin{array}{r}.79 \\
\pm .058 \\
\end{array}$ & $\begin{array}{r}.0176 \\
\pm .001 \\
\end{array}$ & $\begin{array}{c}4.0 \\
\pm .277 \\
\end{array}$ & $\begin{array}{r}90.81 \\
\pm .006 \\
\end{array}$ & $\begin{array}{r}24.46 \\
\pm .058 \\
\end{array}$ & $\begin{array}{c}13.520 \\
\pm .006 \\
\end{array}$ & $\begin{array}{l}0.304 \\
\pm .000 \\
\end{array}$ \\
\hline & $1 \mathrm{mM}$ & $\begin{array}{c}.74^{*} \\
\pm .006\end{array}$ & $\begin{array}{l}.0197 * \\
\pm .001\end{array}$ & $\begin{array}{c}4.6^{*} \\
\pm .058\end{array}$ & $\begin{array}{l}95.77 \\
\pm .006\end{array}$ & $\begin{array}{l}19.07 \\
\pm .006\end{array}$ & $\begin{array}{c}15.020 \\
\pm .006\end{array}$ & $\begin{array}{l}0.342 \\
\pm .000\end{array}$ \\
\hline & $200 \mathrm{mM}$ & $\begin{array}{c}.72 * \\
\pm .011\end{array}$ & $\begin{array}{l}.0153^{*} \\
\pm .000\end{array}$ & $\begin{array}{c}3.1^{*} \\
\pm .058\end{array}$ & $\begin{array}{l}71.69 \\
\pm .058\end{array}$ & $\begin{array}{l}17.25 \\
\pm .058\end{array}$ & $\begin{array}{c}15.770 \\
\pm .058\end{array}$ & $\begin{array}{l}2.025 \\
\pm .006\end{array}$ \\
\hline & $400 \mathrm{mM}$ & $\begin{array}{c}1.22 \\
\pm .064\end{array}$ & $\begin{array}{l}.0073 \\
\pm .000\end{array}$ & $\begin{array}{c}2.7 * \\
\pm .058\end{array}$ & $\begin{array}{c}6.09 \\
\pm .577\end{array}$ & $\begin{array}{l}16.81 \\
\pm .006\end{array}$ & $\begin{array}{l}18.023 \\
\pm .006\end{array}$ & $\begin{array}{l}3.644 \\
\pm .000\end{array}$ \\
\hline & $600 \mathrm{mM}$ & $\begin{array}{c}1.47 \\
\pm .058\end{array}$ & $\begin{array}{l}.0026 \\
\pm .000\end{array}$ & $\begin{array}{c}2.3 \\
\pm .058\end{array}$ & $\begin{array}{c}5.58 \\
\pm .058\end{array}$ & $\begin{array}{l}13.47 \\
\pm .058\end{array}$ & $\begin{array}{l}19.520 \\
\pm .006\end{array}$ & $\begin{array}{l}3.883 \\
\pm .000\end{array}$ \\
\hline & $800 \mathrm{mM}$ & $\begin{array}{c}1.48 \\
\pm .115 \\
\end{array}$ & $\begin{array}{l}.0013 \\
\pm .000 \\
\end{array}$ & $\begin{array}{r}2.3 \\
\pm .058 \\
\end{array}$ & $\begin{array}{c}4.18 \\
\pm .006 \\
\end{array}$ & $\begin{array}{r}9.38 \\
\pm .173 \\
\end{array}$ & $\begin{array}{l}19.550 \\
\pm .058 \\
\end{array}$ & $\begin{array}{l}4.333 \\
\pm .000 \\
\end{array}$ \\
\hline & $1000 \mathrm{mM}$ & $\begin{array}{r}1.50 \\
\pm .058 \\
\end{array}$ & $\begin{array}{c}.000 \\
\pm .000 \\
\end{array}$ & $\begin{array}{c}2.0 \\
\pm .177 \\
\end{array}$ & $\begin{array}{c}3.29 \\
\pm .115 \\
\end{array}$ & $\begin{array}{c}8.48 \\
\pm .058 \\
\end{array}$ & $\begin{array}{l}20.27 \\
\pm .058 \\
\end{array}$ & $\begin{array}{l}6.510 \\
\pm .006 \\
\end{array}$ \\
\hline & $1200 \mathrm{mM}$ & $\begin{array}{c}2.00 \\
\pm .077 \\
\end{array}$ & $\begin{array}{c}.000 \\
\pm .000 \\
\end{array}$ & $\begin{array}{r}2.0 \\
\pm .155 \\
\end{array}$ & $\begin{array}{r}1.90 \\
\pm .177 \\
\end{array}$ & $\begin{array}{c}6.46 \\
\pm .058 \\
\end{array}$ & $\begin{array}{l}21.026 \\
\pm .006 \\
\end{array}$ & $\begin{array}{l}7.030 \\
\pm .006 \\
\end{array}$ \\
\hline & L.S.D & 0.636 & 0.008 & 1.505 & 0.879 & 0.232 & 0.109 & 0.009 \\
\hline \multirow[t]{9}{*}{$\begin{array}{l}\mathrm{ZnSO4+} \\
\mathrm{Ca}(\mathrm{NO3})_{2}\end{array}$} & Control & $\begin{array}{c}.77 \\
\pm .006 \\
\end{array}$ & $\begin{array}{l}.0431 \\
\pm .000 \\
\end{array}$ & $\begin{array}{c}5.7 \\
\pm .058 \\
\end{array}$ & $\begin{array}{c}103.70 \\
\pm .058 \\
\end{array}$ & $\begin{array}{c}30.246 \\
\pm .058 \\
\end{array}$ & $\begin{array}{l}13.520 \\
\pm .006 \\
\end{array}$ & $\begin{array}{c}.125 \\
\pm .006 \\
\end{array}$ \\
\hline & $1 \mathrm{mM}$ & $\begin{array}{c}.76^{*} \\
\pm .006 \\
\end{array}$ & $\begin{array}{l}.0461^{*} \\
\pm .000\end{array}$ & $\begin{array}{c}6.0^{*} \\
\pm .577 \\
\end{array}$ & $\begin{array}{l}116.63 \\
\pm .006\end{array}$ & $\begin{array}{c}25.982 \\
\pm .000 \\
\end{array}$ & $\begin{array}{c}13.520 * \\
\pm .011\end{array}$ & $\begin{array}{l}.127^{*} \\
\pm .006 \\
\end{array}$ \\
\hline & $200 \mathrm{mM}$ & $\begin{array}{c}.71 * \\
\pm .058 \\
\end{array}$ & $\begin{array}{l}.0312^{*} \\
\pm .000 \\
\end{array}$ & $\begin{array}{r}3.2 \\
\pm .058 \\
\end{array}$ & $\begin{array}{l}79.51 \\
\pm .006 \\
\end{array}$ & $\begin{array}{l}25.791 \\
\pm .000 \\
\end{array}$ & $\begin{array}{l}15.020 \\
\pm .006 \\
\end{array}$ & $\begin{array}{l}0.218 \\
\pm .000 \\
\end{array}$ \\
\hline & $400 \mathrm{mM}$ & $\begin{array}{c}1.27 \\
\pm .058 \\
\end{array}$ & $\begin{array}{l}.0270 \\
\pm .000 \\
\end{array}$ & $\begin{array}{r}3.0 \\
\pm .277 \\
\end{array}$ & $\begin{array}{l}26.32 \\
\pm .006 \\
\end{array}$ & $\begin{array}{l}23.801 \\
\pm .000 \\
\end{array}$ & $\begin{array}{l}18.027 \\
\pm .000 \\
\end{array}$ & $\begin{array}{l}0.493 \\
\pm .000 \\
\end{array}$ \\
\hline & $600 \mathrm{mM}$ & $\begin{array}{c}1.61 \\
\pm .058 \\
\end{array}$ & $\begin{array}{r}.0240 \\
\pm .006 \\
\end{array}$ & $\begin{array}{c}3.0 \\
\pm .077 \\
\end{array}$ & $\begin{array}{r}15.86 \\
\pm .006 \\
\end{array}$ & $\begin{array}{l}23.163 \\
\pm .000 \\
\end{array}$ & $\begin{array}{c}19.529 \\
\pm .058 \\
\end{array}$ & $\begin{array}{l}0.581 \\
\pm .000 \\
\end{array}$ \\
\hline & $800 \mathrm{mM}$ & $\begin{array}{c}2.21 \\
\pm .006 \\
\end{array}$ & $\begin{array}{l}.0211 \\
\pm .000 \\
\end{array}$ & $\begin{array}{c}3.0 \\
\pm .155 \\
\end{array}$ & $\begin{array}{l}12.18 \\
\pm .006 \\
\end{array}$ & $\begin{array}{l}22.581 \\
\pm .000 \\
\end{array}$ & $\begin{array}{c}19.529 \\
\pm .006 \\
\end{array}$ & $\begin{array}{l}0.847 \\
\pm .006 \\
\end{array}$ \\
\hline & $1000 \mathrm{mM}$ & $\begin{array}{c}2.23 \\
\pm .006 \\
\end{array}$ & $\begin{array}{l}.0207 \\
\pm .000 \\
\end{array}$ & $\begin{array}{c}3.0 \\
\pm .077 \\
\end{array}$ & $\begin{array}{c}9.39 \\
\pm .058 \\
\end{array}$ & $\begin{array}{c}21.302 \\
\pm .000 \\
\end{array}$ & $\begin{array}{c}20.278 \\
\pm .058 \\
\end{array}$ & $\begin{array}{l}1.234 \\
\pm .000 \\
\end{array}$ \\
\hline & $1200 \mathrm{mM}$ & $\begin{array}{c}2.28 \\
\pm .058 \\
\end{array}$ & $\begin{array}{r}.0179 \\
\pm .001 \\
\end{array}$ & $\begin{array}{c}3.0 \\
\pm .077 \\
\end{array}$ & $\begin{array}{c}3.80 \\
\pm .058 \\
\end{array}$ & $\begin{array}{c}18.174 \\
\pm .000\end{array}$ & $\begin{array}{c}21.030 \\
\pm .006\end{array}$ & $\begin{array}{r}1.300 \\
\pm .058 \\
\end{array}$ \\
\hline & L.S.D & 0.109 & 0.012 & 2.124 & 0.134 & 0.095 & 0.095 & 0.055 \\
\hline \multirow[t]{3}{*}{$\begin{array}{l}\text { ZnSO4+ } \\
\text { glutathione }\end{array}$} & Control & $\begin{array}{c}0.75 \\
\pm .006 \\
\end{array}$ & $\begin{array}{r}.0329 \\
\pm .000 \\
\end{array}$ & $\begin{array}{r}4.8 \\
\pm .058 \\
\end{array}$ & $\begin{array}{r}92.84 \\
\pm .006 \\
\end{array}$ & $\begin{array}{c}26.076 \\
\pm .000 \\
\end{array}$ & $\begin{array}{l}18.027 \\
\pm .006\end{array}$ & $\begin{array}{l}0.134 \\
\pm .000 \\
\end{array}$ \\
\hline & $1 \mathrm{mM}$ & $\begin{array}{l}0.68^{*} \\
\pm .058 \\
\end{array}$ & $\begin{array}{l}.0279^{*} \\
\pm .002 \\
\end{array}$ & $\begin{array}{c}5.0^{*} \\
\pm .577 \\
\end{array}$ & $\begin{array}{r}96.19 \\
\pm .058 \\
\end{array}$ & $\begin{array}{c}20.741 \\
\pm .000 \\
\end{array}$ & $\begin{array}{l}19.520 \\
\pm .006 \\
\end{array}$ & $\begin{array}{l}0.151 \\
\pm .006 \\
\end{array}$ \\
\hline & $200 \mathrm{mM}$ & $\begin{array}{l}0.70^{*} \\
\pm .058\end{array}$ & $\begin{array}{r}.0218 \\
\pm .000\end{array}$ & $\begin{array}{c}3.3 \\
\pm .058\end{array}$ & $\begin{array}{r}25.06 \\
\pm .006\end{array}$ & $\begin{array}{c}19.271 \\
\pm .000\end{array}$ & $\begin{array}{c}19.520 \\
\pm .058\end{array}$ & $\begin{array}{l}0.533 \\
\pm .000\end{array}$ \\
\hline
\end{tabular}


DOI: 10.5281/zenodo.3556846

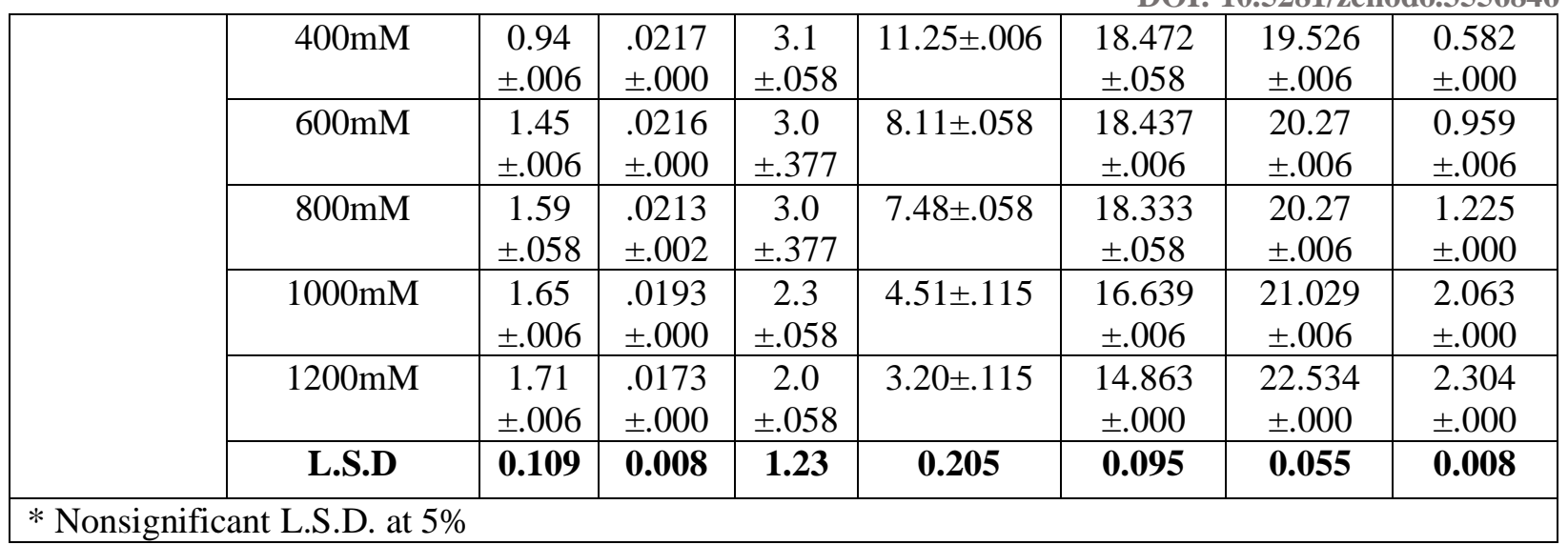

Table 2: Effect of different $\mathrm{ZnSO} 4$ concentrations in the culture medium either alone or in combination with $(10 \mathrm{mM}) \mathrm{Ca}(\mathrm{NO} 3) 2$ or glutathione on the zinc content in root in shoot and in the total uptake of 14-day-old Phaseolus vulgaris plants .Each value is the mean of 3 Sample calculated as m mole $100 \mathrm{~g}-1$ dry weight

\begin{tabular}{|c|c|c|c|c|}
\hline Treatment & Concentrations & Zn in Root & Zn in Shoot & Total uptake of $\mathrm{Zn}$ \\
\hline \multirow[t]{9}{*}{ ZnSO4 } & Control & $0.333 \pm .008$ & $0.073 \pm .002$ & $0.406 \pm .000$ \\
\hline & $1 \mathrm{mM}$ & $0.416 * \pm .000$ & $0.087 * \pm .000$ & $0.503 * \pm .000$ \\
\hline & $200 \mathrm{mM}$ & $22.51 \pm .058$ & $1.36 \pm .006$ & $23.87 \pm .006$ \\
\hline & $400 \mathrm{mM}$ & $28.78 \pm .006$ & $1.73 \pm .006$ & $30.51 \pm .058$ \\
\hline & $600 \mathrm{mM}$ & $31.73 \pm .006$ & $2.00 \pm .577$ & $33.75 \pm .058$ \\
\hline & $800 \mathrm{mM}$ & $34.76 \pm .006$ & $2.74 \pm .006$ & $37.50 \pm .058$ \\
\hline & $1000 \mathrm{mM}$ & $35.91 \pm .006$ & $3.78 \pm .006$ & $39.69 \pm .058$ \\
\hline & $1200 \mathrm{mM}$ & $35.91 \pm .006$ & $4.55 \pm .006$ & $40.46 \pm .115$ \\
\hline & L.S.D & 0.095 & 0.612 & $\mathbf{0 . 1 7 3}$ \\
\hline \multirow[t]{9}{*}{$\mathrm{ZnSO4+} \mathrm{Ca}(\mathrm{NO3}) 2$} & Control & $0.27 \pm .002$ & $0.068 \pm .000$ & $0.338 \pm .006$ \\
\hline & $1 \mathrm{mM}$ & $0.60 * \pm .005$ & $0.075^{*} \pm .000$ & $0.675 \pm .006$ \\
\hline & $200 \mathrm{mM}$ & $4.55 \pm .006$ & $1.23 * \pm .058$ & $5.78 \pm .000$ \\
\hline & $400 \mathrm{mM}$ & $11.97 \pm .006$ & $1.27 * \pm .006$ & $13.24 \pm .000$ \\
\hline & $600 \mathrm{mM}$ & $18.45 \pm .012$ & $1.32 \pm .012$ & $19.77 \pm .000$ \\
\hline & $800 \mathrm{mM}$ & $28.84 \pm .006$ & $1.77 \pm .006$ & $30.61 \pm .001$ \\
\hline & $1000 \mathrm{mM}$ & $32.67 \pm .006$ & $2.13 \pm .155$ & $34.80 \pm .000$ \\
\hline & $1200 \mathrm{mM}$ & $33.00 \pm .577$ & $2.70 \pm .058$ & $35.70 \pm .000$ \\
\hline & L.S.D & 0.627 & 1.228 & 0.008 \\
\hline \multirow[t]{9}{*}{ ZnSO4+ glutathione } & Control & $0.52 \pm .006$ & $0.108 \pm .000$ & $0.628 \pm .000$ \\
\hline & $1 \mathrm{mM}$ & $0.69 \pm .058$ & $.160 * \pm .006$ & $0.85 \pm .012$ \\
\hline & $200 \mathrm{mM}$ & $17.32 \pm .006$ & $1.303 \pm .000$ & $18.623 \pm .012$ \\
\hline & $400 \mathrm{mM}$ & $24.43 \pm .006$ & $1.460 \pm .006$ & $25.89 \pm .058$ \\
\hline & $600 \mathrm{mM}$ & $29.84 \pm .006$ & $1.598 \pm .000$ & $31.438 \pm .058$ \\
\hline & $800 \mathrm{mM}$ & $35.24 \pm .006$ & $1.656 \pm .001$ & $36.896 \pm .000$ \\
\hline & $1000 \mathrm{mM}$ & $36.93 \pm .006$ & $2.679 \pm .077$ & $39.609 \pm .058$ \\
\hline & $1200 \mathrm{mM}$ & $61.63 \pm .006$ & $5.039 \pm .006$ & $66.669 \pm .058$ \\
\hline & L.S.D & 0.055 & 0.612 & 0.122 \\
\hline
\end{tabular}


Table 3: Effect of $\mathrm{ZnSO} 4$ concentrations either alone or incombination with (10 Mm) $\mathrm{Ca}(\mathrm{NO} 3) 2$ or glutathione on the root anatomy of 14-day-old aseolus vulgaris Each value is the mean of 3 samples.

\begin{tabular}{|c|c|c|c|c|}
\hline Treatment & Concentration & 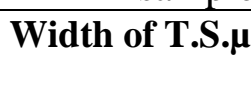 & Width of cortex $\mu$ & $\begin{array}{l}\text { Width of vascular } \\
\text { bundle } \mu\end{array}$ \\
\hline \multirow[t]{6}{*}{$\mathrm{ZnSO} 4$} & Control & $60.9 \pm .058$ & $16.8 \pm .058$ & $25.2 \pm .115$ \\
\hline & $1 \mathrm{mM}$ & $64.05 \pm .006$ & $21.0 \pm .577$ & $29.4 \pm .058$ \\
\hline & $200 \mathrm{mM}$ & $68.95 \pm .577$ & $23.1 \pm .058$ & $31.5 \pm .577$ \\
\hline & $600 \mathrm{mM}$ & $78.75 \pm .006$ & $25.2 \pm .887$ & $42.0 \pm .155$ \\
\hline & $1200 \mathrm{mM}$ & $100.8 \pm .058$ & $31.5 \pm .289$ & $52.5 \pm .289$ \\
\hline & L.S.D & 0.822 & 4.169 & 1.873 \\
\hline \multirow{6}{*}{$\begin{array}{l}\mathrm{ZnSO} 4+ \\
\mathrm{Ca}(\mathrm{NO} 3) 2\end{array}$} & Control & $70.35 \pm .058$ & $17.85 \pm .006$ & $24.15 \pm 1.155$ \\
\hline & $1 \mathrm{mM}$ & $73.5 \pm .058$ & $18.9 * \pm .577$ & $26.25^{*} \pm .006$ \\
\hline & $200 \mathrm{mM}$ & $75.6 \pm .058$ & $19.95 \pm .006$ & $31.5 \pm .058$ \\
\hline & $600 \mathrm{mM}$ & $76.65 \pm .006$ & $21.0 \pm .577$ & $33.6 \pm .115$ \\
\hline & $1200 \mathrm{mM}$ & $105.0 \pm .577$ & $35.7 \pm .058$ & $42 \pm 1.155$ \\
\hline & L.S.D & 0.826 & 1.154 & 2.308 \\
\hline \multirow{6}{*}{$\begin{array}{l}\text { ZnSO4+ } \\
\text { glutathione }\end{array}$} & Control & $69.3 \pm .058$ & $23.1 \pm .058$ & $31.5 \pm .577$ \\
\hline & $1 \mathrm{mM}$ & $73.50 \pm .577$ & $26.25 \pm .006$ & $34.65 \pm .006$ \\
\hline & $200 \mathrm{mM}$ & $75.60 \pm .115$ & $31.50 \pm .577$ & $36.75 \pm .006$ \\
\hline & $600 \mathrm{mM}$ & $97.65 \pm .006$ & $36.75 \pm .006$ & $45.15 \pm .006$ \\
\hline & $1200 \mathrm{mM}$ & $105.0 \pm 1.155$ & $42.0 \pm .155$ & $46.2 \pm .115$ \\
\hline & L.S.D & 1.828 & 1.821 & 0.829 \\
\hline
\end{tabular}

Table 4: Effect of ZnSO4 concentrations either alone or incombination with (10 Mm) $\mathrm{Ca}(\mathrm{NO} 3) 2$ or glutathione on the stem anatomy of 14-day-old Phaseolus vulgaris Each value is the mean of 3 samples

\begin{tabular}{|l|c|c|c|c|}
\hline Treatment & Concentration & $\begin{array}{c}\text { Number of rows of } \\
\text { cortical cells }\end{array}$ & $\begin{array}{c}\text { with of cortex } \\
\boldsymbol{\mu}\end{array}$ & $\begin{array}{c}\text { Number of vascular } \\
\text { bundle }\end{array}$ \\
\hline \multirow{5}{*}{$\mathrm{ZnSO} 4$} & Control & $10 \pm .887$ & $157.5 \pm .289$ & $23.0 \pm .577$ \\
\cline { 2 - 5 } & $1 \mathrm{mM}$ & $6^{*} \pm .577$ & $136.5 \pm .577$ & $22^{*} \pm 1.155$ \\
\cline { 2 - 5 } & $200 \mathrm{mM}$ & $6^{*} \pm .155$ & $115.5 \pm 2.887$ & $21^{*} \pm 1.155$ \\
\cline { 2 - 5 } & $600 \mathrm{mM}$ & $5 \pm .155$ & $105 \pm .577$ & $21^{*} \pm 1.732$ \\
\cline { 2 - 5 } & $1200 \mathrm{mM}$ & $5 \pm .4$ & $105 \pm 2.887$ & $20.0 * \pm .577$ \\
\cline { 2 - 5 } $\mathrm{ZnSO} 4+$ & L.S.D & 4.813 & 5.881 & 3.546 \\
\hline \multirow{5}{*}{$\mathrm{Ca}(\mathrm{NO} 3) 2$} & Control & $11 \pm .577$ & $168.0 \pm .577$ & $24 \pm .577$ \\
\cline { 2 - 5 } & $1 \mathrm{mM}$ & $7 \pm .155$ & $157.5 \pm .289$ & $21 \pm 1.155$ \\
\cline { 2 - 5 } & $200 \mathrm{mM}$ & $6 \pm .155$ & $126.0 \pm .577$ & $11.0 \pm .577$ \\
\cline { 2 - 5 } & $600 \mathrm{mM}$ & $6 \pm .577$ & $115.5 \pm .577$ & $10 \pm 1.155$ \\
\cline { 2 - 5 } & $1200 \mathrm{mM}$ & $6 \pm .732$ & $115.5 \pm .058$ & $20 \pm .577$ \\
\cline { 2 - 5 } & L.S.D & 3.546 & 1.469 & 2.698 \\
\hline & Control & $13 \pm .577$ & $199.5 \pm .058$ & $21 \pm .577$ \\
\cline { 2 - 5 } & $1 \mathrm{mM}$ & $8 \pm .155$ & $189 * \pm 5.77$ & $26 \pm 1.155$ \\
\cline { 2 - 5 } & $200 \mathrm{mM}$ & $8 \pm .577$ & $168.0 \pm 5.77$ & $29 \pm .577$ \\
\hline
\end{tabular}




\begin{tabular}{|l|c|c|c|c|}
\hline \multirow{2}{*}{$\begin{array}{l}\text { ZnSO4+ } \\
\text { glutathione }\end{array}$} & $600 \mathrm{mM}$ & $7 \pm .155$ & $157.5 \pm .289$ & $30 \pm 1.155$ \\
\cline { 2 - 5 } & $1200 \mathrm{mM}$ & $6 \pm .155$ & $157.5 \pm .058$ & $30 \pm .577$ \\
\cline { 2 - 5 } & L.S.D & 3.04 & 11.513 & 2.698 \\
\hline
\end{tabular}

Table 5: Effect of ZnSO4 concentrations either alone or incombination with (10 Mm) Ca (NO3)2 or glutathione on the leaf anatomy of 14-day-old Phaseolus vulgaris Each value is the mean of 3 samples.

\begin{tabular}{|c|c|c|c|c|}
\hline Treatment & Concentrations & $\begin{array}{c}\text { blade } \\
\text { thickness } \mu\end{array}$ & $\begin{array}{l}\text { Midrib } \mu \\
\text { thickness }\end{array}$ & Width of vascular bundle $\mu$ \\
\hline \multirow[t]{6}{*}{$\mathrm{ZnSO} 4$} & Control & $9.9750 \pm .000$ & $76.125 \pm .577$ & $18.375 \pm .058$ \\
\hline & $1 \mathrm{mM}$ & $9.975 * \pm .006$ & $78.75 \pm .006$ & $21.0 \pm .577$ \\
\hline & $200 \mathrm{mM}$ & $11.130 \pm .577$ & $86.10 \pm .058$ & $24.15 \pm .577$ \\
\hline & $600 \mathrm{mM}$ & $11.550 \pm .064$ & $90.30 \pm .173$ & $24.15 \pm 1.155$ \\
\hline & $1200 \mathrm{mM}$ & $18.375 \pm .058$ & $96.075 \pm .000$ & $25.20 \pm .115$ \\
\hline & L.S.D & 0.822 & 0.853 & 2.001 \\
\hline \multirow{6}{*}{$\begin{array}{l}\mathrm{ZnSO4+} \\
\mathrm{Ca}(\mathrm{NO} 3) 2\end{array}$} & Control & $11.02 \pm .006$ & $84.0 \pm .577$ & $21.0 \pm .577$ \\
\hline & $1 \mathrm{mM}$ & $11.55 \pm .064$ & $84 * \pm 1.155$ & $25.2 \pm .115$ \\
\hline & $200 \mathrm{mM}$ & $12.92 \pm .006$ & $94.5 \pm .577$ & $26.25 \pm .006$ \\
\hline & $600 \mathrm{mM}$ & $6.30 \pm .173$ & $79.8 \pm .058$ & $16.8 \pm .058$ \\
\hline & $1200 \mathrm{mM}$ & $6.30 \pm .058$ & $78.7 \pm .058$ & $15.75 \pm .006$ \\
\hline & L.S.D & 0.269 & 1.996 & 0.834 \\
\hline \multirow{6}{*}{$\begin{array}{l}\text { ZnSO4+ } \\
\text { glutathione }\end{array}$} & Control & $10.5 \pm .577$ & $89.25 \pm .058$ & $26.25 \pm .006$ \\
\hline & $1 \mathrm{mM}$ & $10.5^{*} \pm .289$ & $87.15 \pm .006$ & $26.25^{*} \pm .577$ \\
\hline & $200 \mathrm{mM}$ & $9.45 * \pm .577$ & $84.0 \pm .577$ & $26.22 * \pm .064$ \\
\hline & $600 \mathrm{mM}$ & $5.780 \pm .058$ & $78.75 \pm .006$ & $26.2 * \pm .115$ \\
\hline & $1200 \mathrm{mM}$ & $2.60 \pm .058$ & $75.6 \pm .115$ & $26.0 * \pm .577$ \\
\hline & L.S.D & 1.226 & 0.834 & 1.165 \\
\hline
\end{tabular}
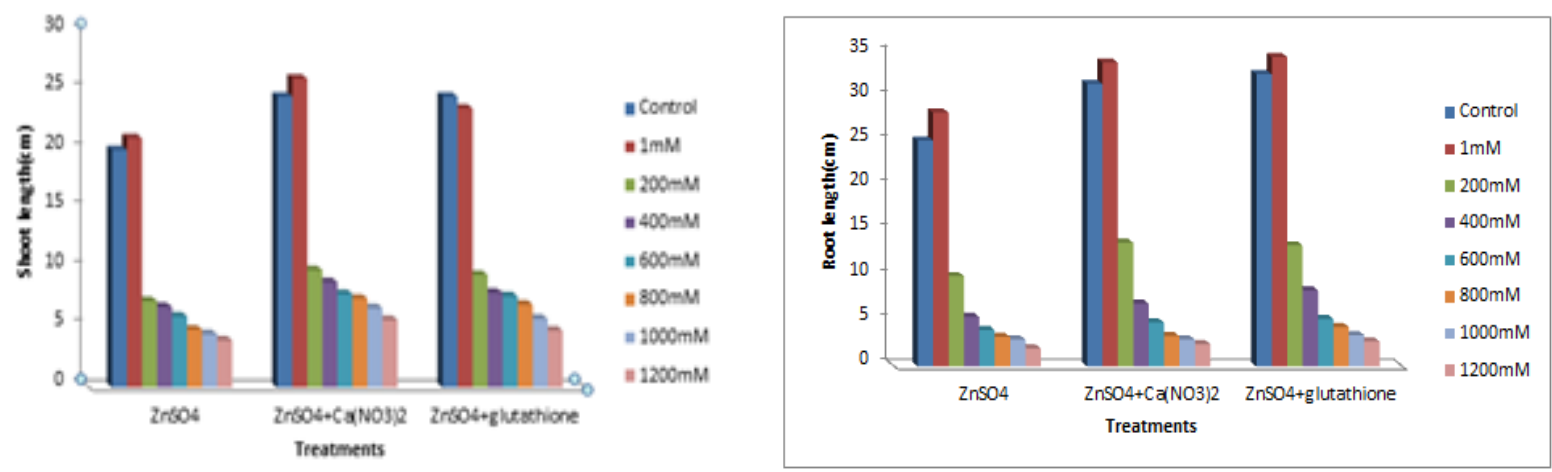


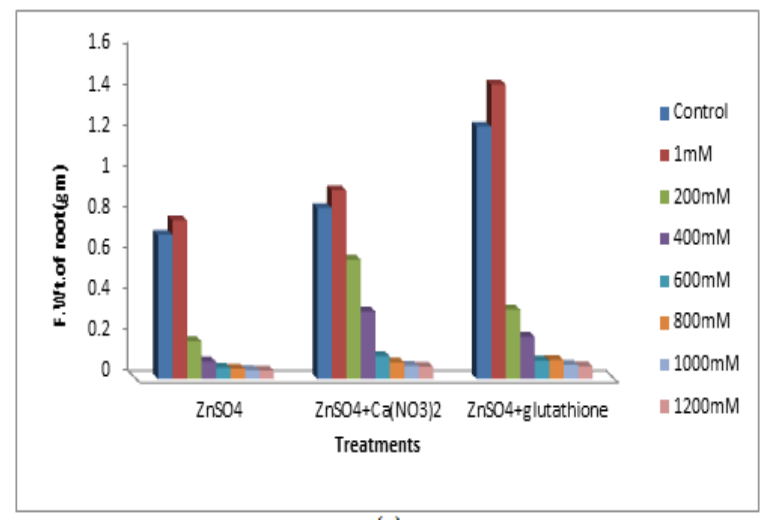

DOI: 10.5281/zenodo.3556846
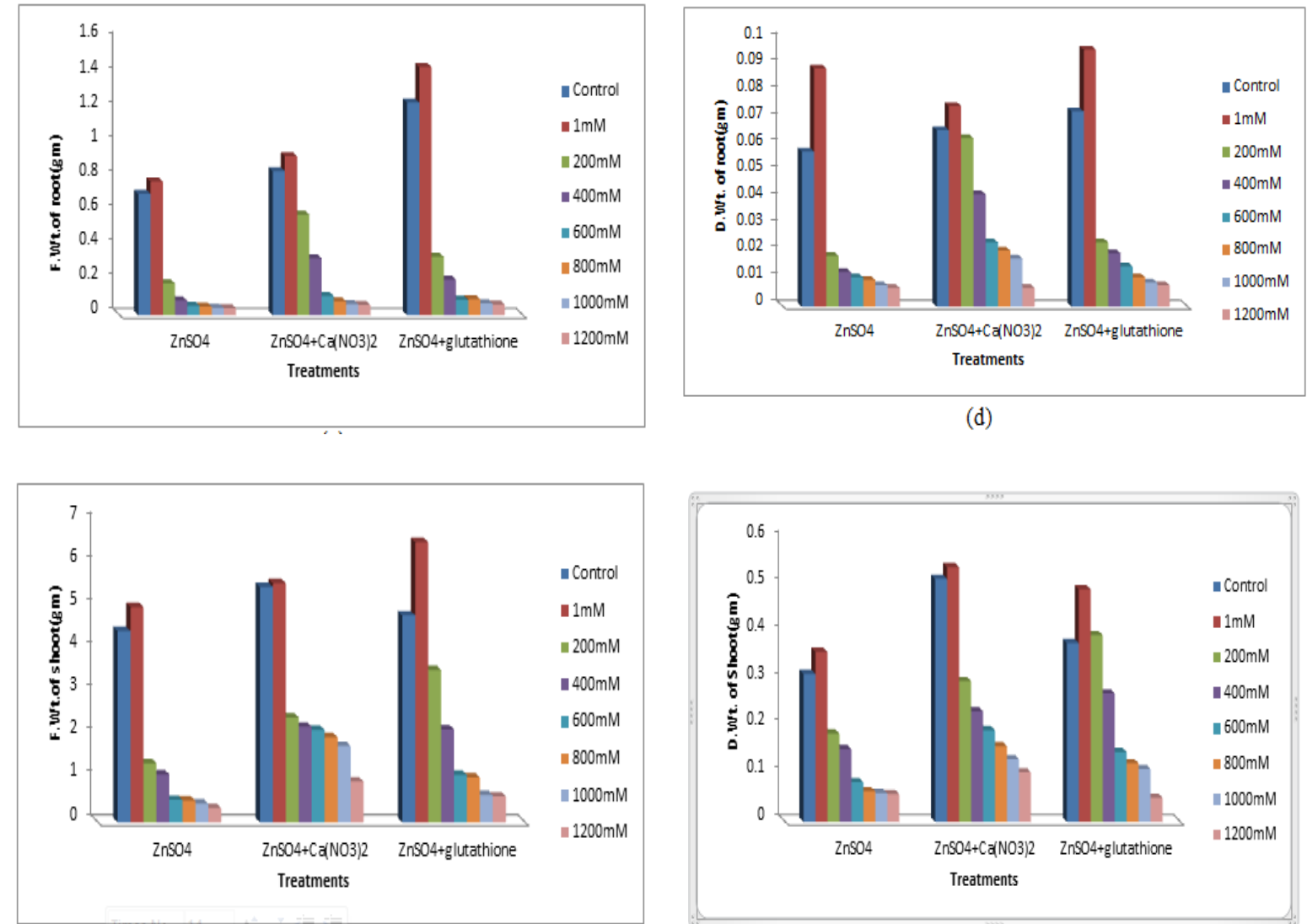

(d)

Figure 1: Effect of different $\mathrm{ZnSO} 4$ concentrations either alone or incombination with (10Mm) $\mathrm{Ca}(\mathrm{NO} 3) 2$ or glutathione on growth parameters(a) root length;(b) shoot length ;(c) fresh weight of root;(d)dry weight of root;(e) fresh weight of shoot;(f) dry weight of shoot;(g) of 14-day- old Phaseolus vulgaris plant.
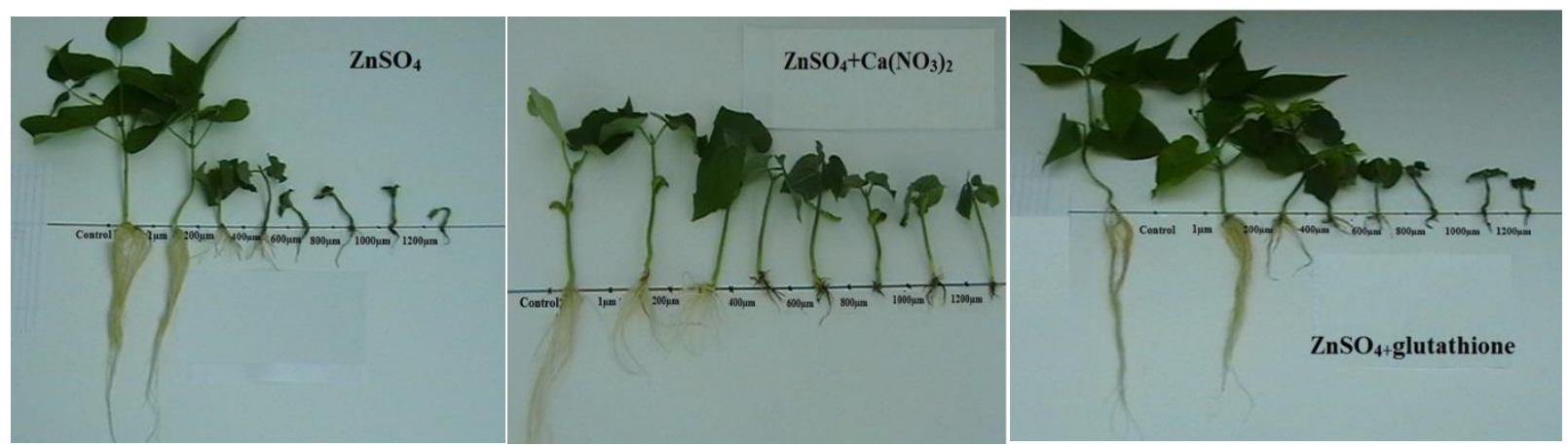

Plate 1: Effect of different Zinc concentrations alone or incombination with (10Mm) $\mathrm{Ca}(\mathrm{NO} 3) 2$ or glutathione on growth of Phaseolus vulgaris plant 


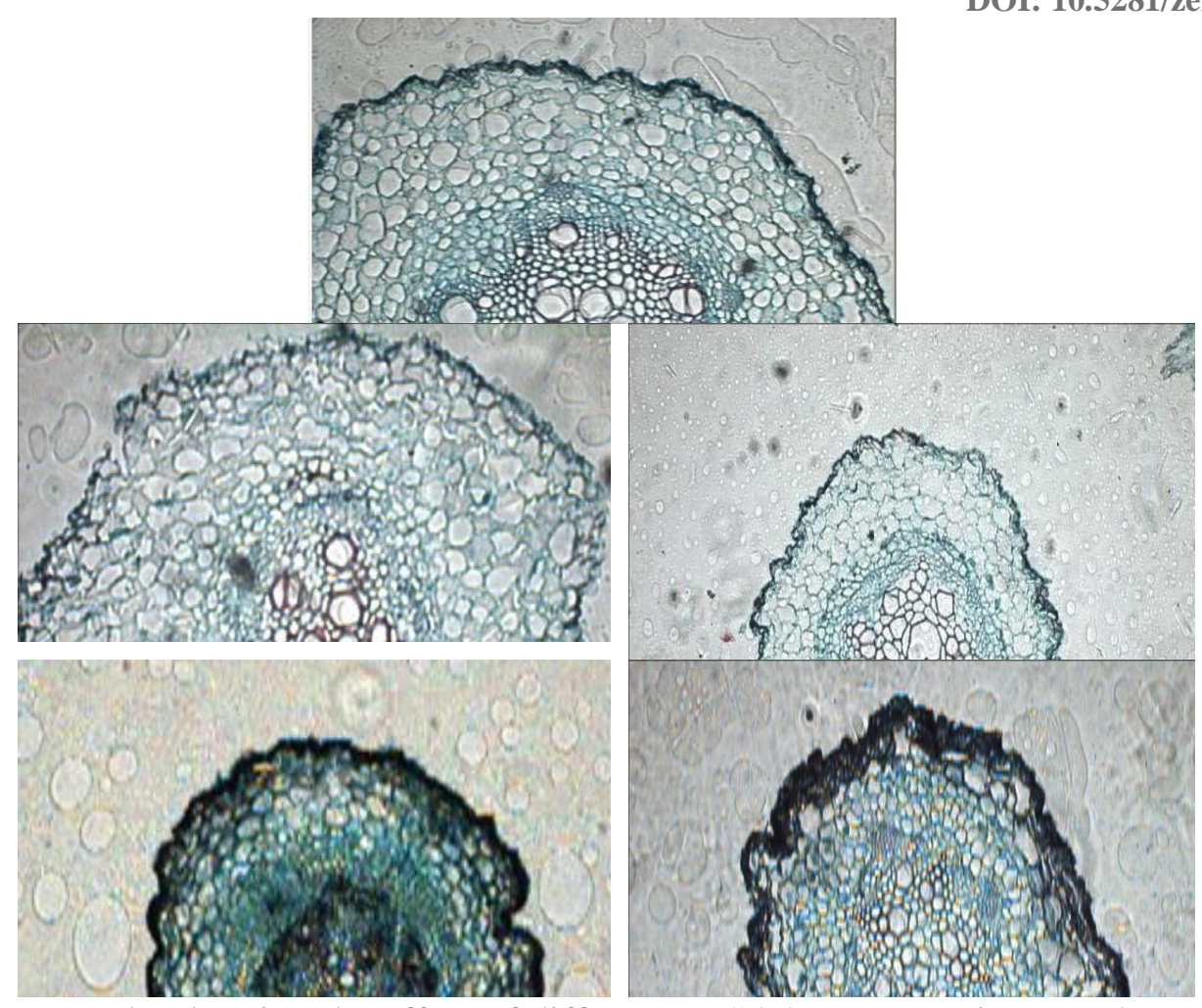

Plate 2: Photographs showing the effect of different $\mathrm{ZnSO} 4$ concentrations on the root anatomy of Phaseolus vulgaris plants. (a) control; (b) 1mM; (c) 200mM; (d) $600 \mathrm{mM}$ and (e) $1200 \mathrm{mM}$.

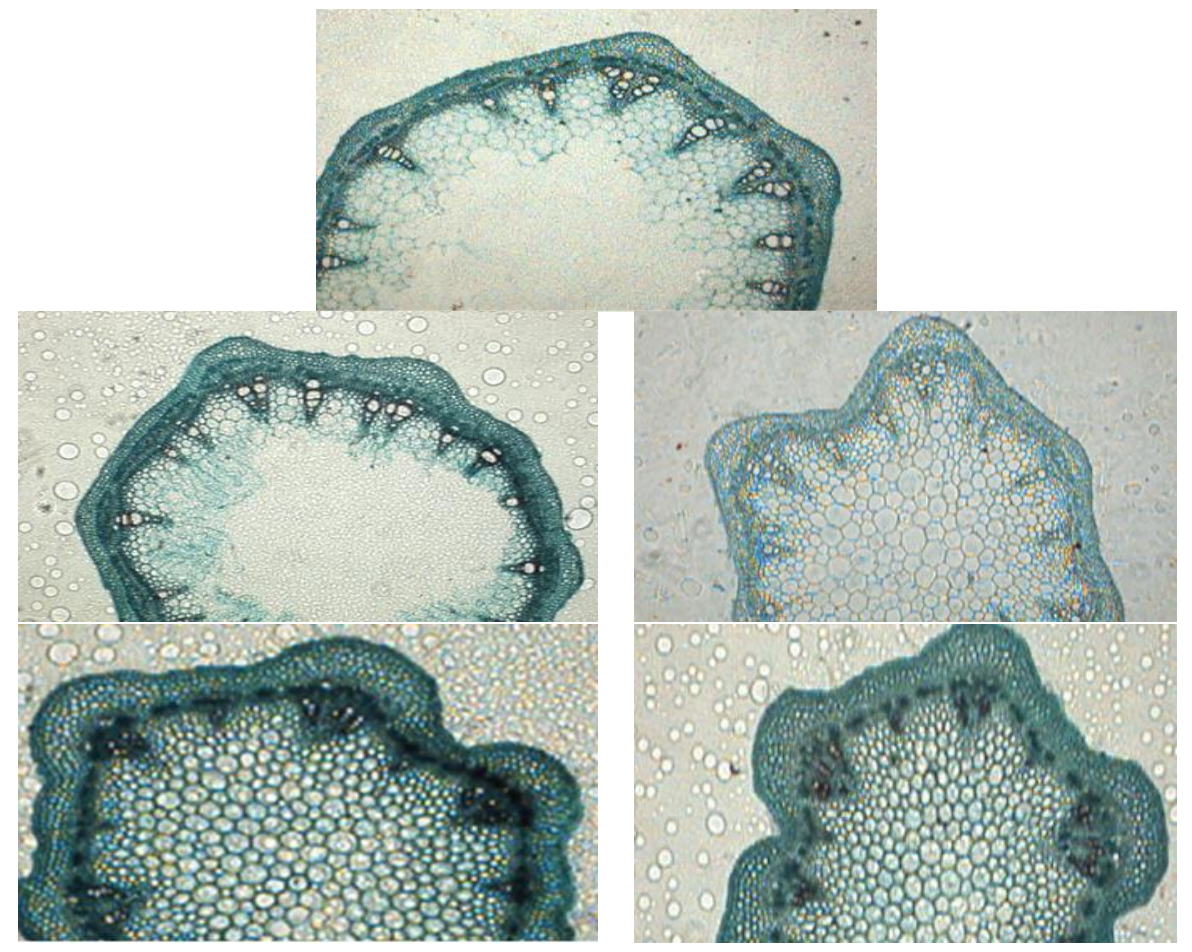

Plate 3: Photographs showing the effect of different $\mathrm{ZnSO}_{4}$ concentrations on the stem anatomy of Phaseolus vulgaris plants. (a) control; (b) 1mM; (c) $200 \mathrm{mM}$; (d) $600 \mathrm{mM}$ and (e) $1200 \mathrm{mM}$. 

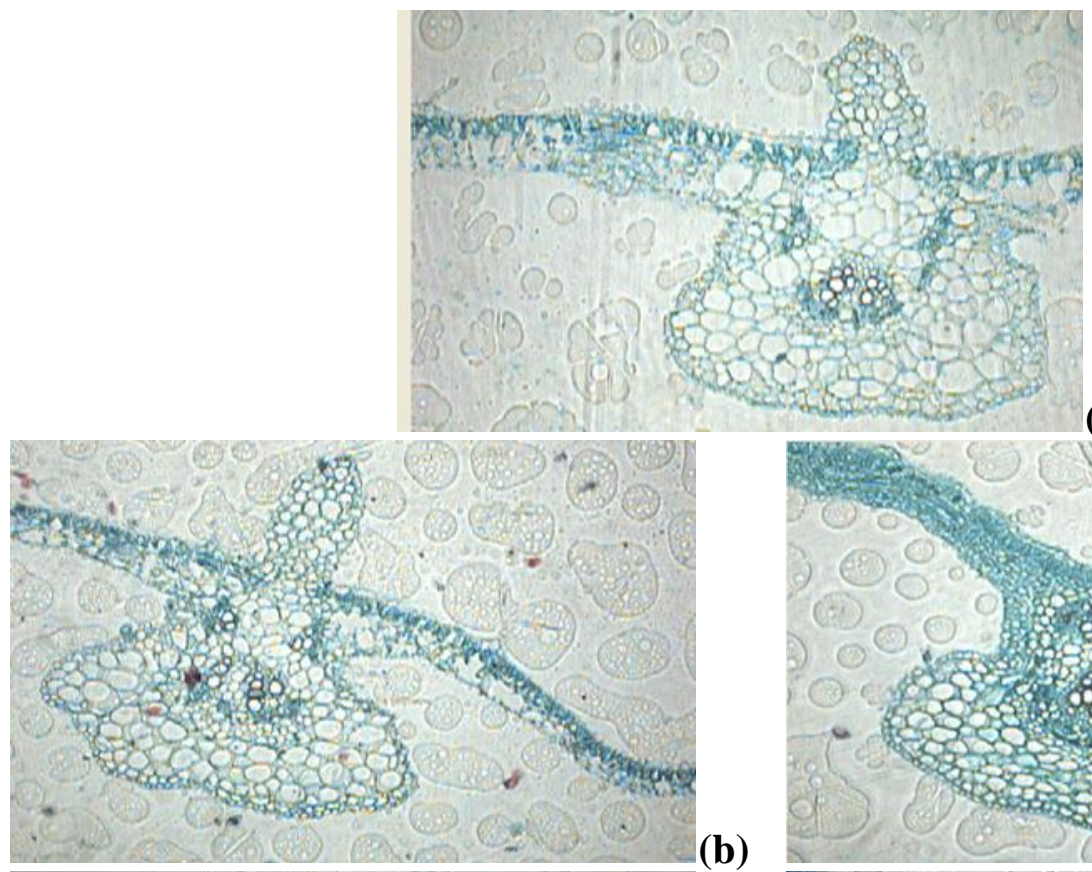

(b)
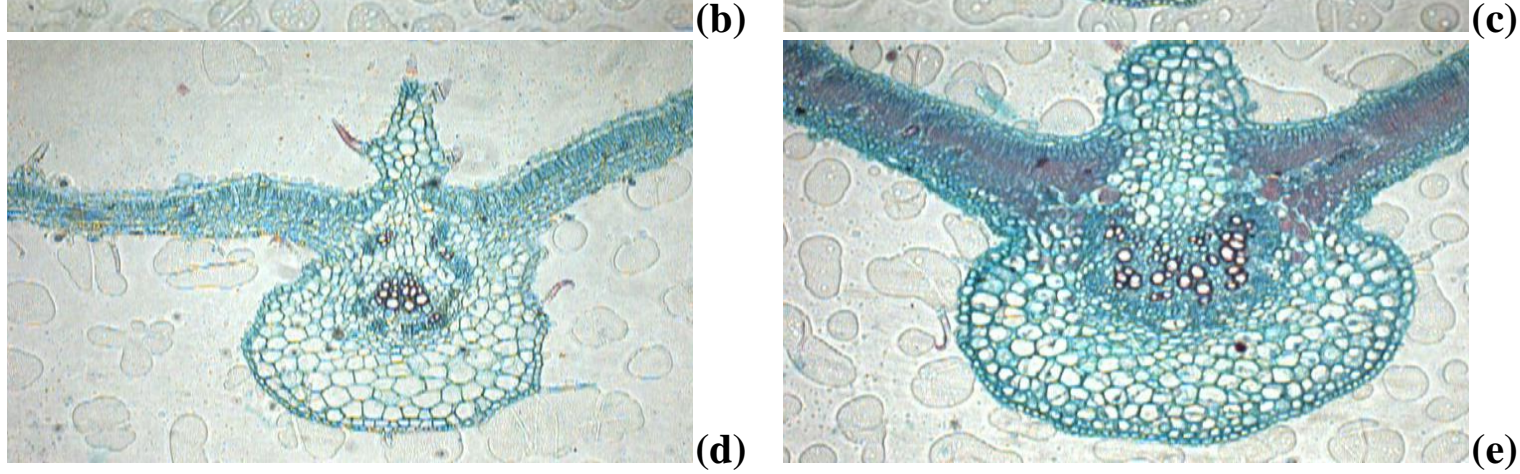

Plate 4: Photographs showing the effect of different $\mathrm{ZnSO} 4$ concentrations on Leaf anatomy of Phaseolus Vulgaris plants. (a) control; (b) $1 \mathrm{mM}$; (c) $200 \mathrm{mM}$; (d) $600 \mathrm{mM}$ and (e) $1200 \mathrm{mM}$

\section{Conflict of Interest}

The authors declare that there is no conflict of interest .

\section{Acknowledgements}

The authors thank in particular King Abdulaziz City for Science and Technology for its support of the research, especially thanks to the team at the Research and Development Center Aramcoa Dhahran and the Royal Commission in Jubail.

\section{References}

[1] Alloway, B. J. (1990): Heavy metals in soil. John Wiley and Sons, Inc. New York.

[2] Alpaslan, M.; Inal, A.; Gunes, A.; Cikili, Y. and Ozcan, H. (1999): Effect of Zinc treatment on alleviation of Sodium and Chloride Injury in tomato (Lycopersicum esculentum L. Mill. CV. Lale) grown under salinity. Tr.J. of Botany 23: 1-6. 
[3] Al-Yemeni, M.N. and Al-Helal, A.A. (2002): Effect of Zinc Chloride and Lead Nitrate on Seed. Germination and Early Seedling Growth of Rice and Alfalfa. J. of King Saud Univ. (Sci) 15: 3947.

[4] Arnon DI, Hoagland DR (1940): Crop production in artificial culture solution and in soil with special reference to factors influencing yields and absorption of inorganic nutrient. Soil Science 50: $436-486$

[5] Bonnet, M.; Camares, O. and Veisseire, P. (2000): Effects of Zinc and influence of Acremonium lolii on growth parameters, chlorophyll a fluorescence and antioxidant enzyme activities of ryegrass (Lolium perenne L. CV Apollo). Journal of experimental Botany. 51: 945-953.

[6] Brennan, R. F. (2005): Zinc Application and Its Availability to Plants. Ph. D. dissertation, School of Environmental Science, Division of Science and Engineering, Murdoch University.

[7] Broadley M.R., White P.J., Hammond J.P., Zelko I., Lux A. (2007): Zinc in plants. New Phytologist, 173: 677-702.

[8] Chamon, A. S.; Mondol, M. N. and Rahman, M. H. (2008): Effects of cadmium and zinc on the yield and nutrient content of spinach. Bangladesh J. Agric. And Environ.,. 4: 107-111.

[9] Chaney, R.L. (1993): Zinc phytotoxicity. In: Robson Ad, ed. Zinc in soil and plants. Dordrecht, the Netherlands: Kluwer Academic Publishers, 135-150.

[10] FAO (2013): Food and Agriculture Organization of the United Nations.

[11] Friedland A. (1990): The movement of metals through soils and ecosystems. In: Shaw A.J. (Ed.), Heavy Metal Tolerance in Plants: Evolutionary Aspects. CRC Press, Boca Raton, FL, USA: 7-19.

[12] Gadallah, M.A.A. and Ramadan, T. (1997): Effect of Zinc and Salinity on growth and anatomical structure of Carthamus tinctorius L. Biologia Planarum. 39: 411-418.

[13] Gentry, Howard Scott (1969). "Origin of the Common Bean, Phaseolus vulgaris". Economic Botany. New York: New York Botanical Garden Press. 23: 55-69.

[14] Hagemeyer J. (1999): Ecophysiology of plant growth under heavy metal stress. In Heavy metal stress in plants - from molecules to ecosystem. Ed. by Prasad MNV, Hagemeyer J. Springer-Verlag, Berlin, Heidelberg, Germany, pp 157-181.

[15] Hall, J.L. (2002): Cellular mechanisms for heavy metal detoxification and tolerance. J. Exp. Bot. 53: $1-11$.

[16] Han FX, Banin A (1997): Long-term transformations and redistribution of potentially toxic heavy metals in arid-zone soils. I: under saturated conditions. Water Air Soil Pollut 95: 399-423

[17] Hao , H.Z.; Zhong, R.G.; X.R and Zhong, X.B. (2012): The Effect of Transpiration for Heavy Metal Uptake of Hyperaccumulators.

[18] Hoffmann, W.A and POORTER , H. (2002) : Avoiding bias in calculations of relative growth rate. Annals of Botany, 90: 37-42

[19] Jozefczak M.: Remans, T; Vangronsveld, J. and Cuypers, A. (2012) Glutathione Is a Key Player in Metal-Induced Oxidative Stress Defenses. Int. J. Mol. Sci. 13: 3145-3175.

[20] Jozefczak, M.; Remans; Vangronsveld, J. and Cuypers, A. (2012): Glutathione Is a Key Player in Metal-Induced Oxidative.

[21] Kasim, W.A. (2007): Physiological Consequences of structural and Ultra-structural change Induced by Zn Stress in Phaseolus Vulgaris. L. Growth and Photosynthetic Appartus. International Journal of Botany. 1: 15-22.

[22] Kawasaki T, Moritsugu M. (1987): Effects of calcium on the absorption and translocation of heavy metals in excised barley roots: Multi-compartment transport box experiment. Plant and Soil 100: 21-34.

[23] Khudsar, T.; Mahmooduzzafar; Iqbal, M. and Sairam, R.K. (2004): Zinc- Induced changes in Morpho- Physiological and Biochemical Parameters in Artemisia annua Biologia Plantarum. 48: 255-260. 
[24] Kinraide, T. B. (2003): Toxicity factors in acidic forest soils. Attempts to evaluate separately the toxic effects of excessive $\mathrm{Al}^{3+}$ and $\mathrm{H}^{+}$and insufficient $\mathrm{Ca}^{2+}$ and $\mathrm{Mg}^{2+}$ upon root elongation. Europ. J. Soil Sci. 54: 513-520.

[25] Kinraide,T. B. (1998): Three mechanisms for the calcium alleviation of mineral toxicities. Plant Physiol. 118: 513-520.

[26] Kinraide,T. B. (1999): Interactions among $\mathrm{Ca}^{2+} \mathrm{Na}^{+}$and $\mathrm{K}^{+}$in salinity toxicity: quantitative resolution of multiple toxic and ameliorative effects. J. Exp. Bot. 50: 1495-1505.

[27] Malik, N.J.; Chamon, A. S.; Mondol, M. N.; Elahi, S. F. and Faiz, S. M. A. (2011): EFFECT OF DIFFERENT LEVELS OF ZINC ON GROWTH AND YIELD OF RED AMARANTH (AMARANTHUS SP.) AND RICE (ORYZA SATIVA, VARIETY-BR49). Journal of the Bangladesh Association of Young Researchers (JBAYR), 1 : 79-91

[28] Marschner, H. (1995): Mineral nutrition of higher plants. 2nd ed., Academic Press, London.

[29] Marschner, H. (1995): Mineral nutrition of higher plants, $2^{\text {nd }}$ edn. London, UK: Academic Press.

[30] Nieboer, E. and Richardson, D.H.S. (1980): The replacement of the non-descript term "heavy metals" by a biologically and chemically significant classification of metal ions. Environ. Pollut. Ser. B1: 3- 26.,

[31] Pfeffer R.L (1900) The mechanism of absorption and translocation. In: The Physiology of Plants (Vol 1), Oxford University Press, London, pp 86-175.

[32] Phipps, D.A. (1981): Chemistry and biochemistry of tracemetals in biological systems, pp: 1-54. In: N.W. Lepp (ed.) Effect of heavy metal pollution on plants.Vol.1, Applied Science Publ., London

[33] Rosolem, C.A.; Sacramento, L.V.S. and Oliveira, D.M.T. (2005): Kinetics of Zinc uptake and anatomy of Roots and leaves of Coffee Trees as affected by Zinc Nutrition. J. of Plant Nutrition, 28: 2101-2112.

[34] Rout, G.R. and Das, P. (2003): Effect of Metal Toxicity on Plant Growth and Metabolism: I: Zinc Agronomie. 23: 3-11.

[35] Saleh, A.A.H.; El-Meleigy, S.A.; Ebad, F.A.; Helmy, M.A.; Jentschke, G. and Godbold, D.L. (1999): Base cations ameliorate $\mathrm{Zn}$ toxicity but not $\mathrm{Cu}$ toxicity in sugar beet (Beta vulgaris). Journal of Plant Nutrition and Soil Science 162: 275-279.

[36] Sass, J.E. (1958): Botanical microtechnique. Iowa St. Univ. Press Ames.

[37] Sedberry, J. E.; Bligh, D. P.; Peterson, F. J. and Amacher, M. C. (1988). Influence of soil pH and application of $\mathrm{Zn}$ on the yield and uptake of selected nutrient elements by rice. Commun. in Soil Sci. Plant Anal., vol. 19: 597-615.

[38] Sedberry, J. E.; Bligh, D. P.; Peterson, F. J. and Amacher, M. C. (1988). Influence of soil pH and application of $\mathrm{Zn}$ on the yield and uptake of selected nutrient elements by rice. Commun. in Soil Sci. Plant Anal., vol. 19: 597-615.

[39] Shaukat, S.S.; Mushtaq, M. and Siddiqui, Z.S. (1999): Effect of Cadmium, Chromium and Lead on Seed Germination, Early Seedling Growth and Phenolic Contents of Parkinsonia aculeate L. and Pennisetum americanun (L.) Schumann. Pak. J. of Biol. Sci., 2: 1307-1313.

[40] Shukry, W.M. (1986) : Effect of Salinity On Phaseolus vulgaris. Ph.D. Thesis. Faculty of Science, Mansoura University, Egypt.

[41] Shute, T. and Macfie, S.M. (2006): Cadmium and Zinc accumulation in soybean: A threat to food safety: Sci. Total Environment 381: 63-73.

[42] Singh,R.P. and Agrawal , M. (2007) :Effects of sewage sludge amendment on heavy metal accumulation and consequent responses of Beta vulgaris plants. Chemosphere, 67, 2229-2240.

[43] Snedecor, G.W and Cochran, W.G. (1980) : Statistical methods. In: Steel RGD, Torrie JH (Eds) Statistical Methods (7th Edn) Iowa State University Press, Ames, IA, pp 10-19

[44] Sresty, T.V.S. and Madhava Rao, K.V. (1999): Ultrastructural alterations in response to zinc and nickel stress in the root cells of pigeonpea, Environ. Exp. Bot. 41: 3-13. 
[45] Sridhar, B.B.M.; Han, F.X.; Diehl, S.V.; Monts, D.L. and Su, Y. (2007): Effect of Zn and Cd accumulation on structural and physiological characteristics of barly plants. Braz.J. plant physiol, 19: $15-22$

[46] Steing Rover, E. (1983): Storage of osmotically active compounds in the tap root of Daucus carota L. Journal of Experimental Botany 34, 425-433

[47] Tiller, K.G. (1989): Heavy metals in soils and their environmental significance, pp: 113-142. In: B, A. Steward (ed.) Advances in soil science vol.9 Springer Verlag, New York.

[48] Tsonev, T. and Lidon, F.J.C.L. (2012): Zinc in plants - An overview. Emir. J. Food Agric. 24: 322333.

[49] Weyers, J.D.B. and Meidner,H. (1990): Methods in Stomatal Research ,1st Edn. Longman Scientific and Technical, Harlow, pp, 129-155.

[50] Woolhouse, H.W. (1983): Toxicity and tolerance in the response of plants to metals, pp: $245-300$ In: O.L. Lange, P.S. Noble, L.B. Osmond and H. Ziegler (eds.). Physiological Plant Ecology III. Responses to the chemical and biological environment. A.P. Gottinger and M.H.Z. Harward. (eds.) Encyclopedia of plant physiology, New Series, Vol.12C, Springer Verlag Berlin.

[51] Younis, M.E., Abbas, M.A., and Shukry, W.M. (1992): Plant growth, metabolism, and adaptation in relation to stress conditions. XVI. Salinity and hormones interactions in affecting, growth, transpiration and ionic relations of Phaseouls vulgaris. Mans. Sci. Bull., 19:41-58.

[52] Zengin, F.K. (2006): The effects of $\mathrm{Co}^{+2}$ and $\mathrm{Zn}^{+2}$ on the contents of protein, abscisic acid, proline and chlorophyll in bean (Phaseolus Vulgaris CV. Strike) seedlings J. Environmental Biol. 27: 441448.

[53] Zengin, F.K. (2006): The effects of $\mathrm{Co}^{+2}$ and $\mathrm{Zn}^{+2}$ on the contents of protein, abscisic acid, proline and chlorophyll in bean (Phaseolus Vulgaris CV. Strike) seedlings J. Environmental Biol. 27: 441448 .

\footnotetext{
*Corresponding author.

E-mail address: wafaa_12@yahoo.com
} 